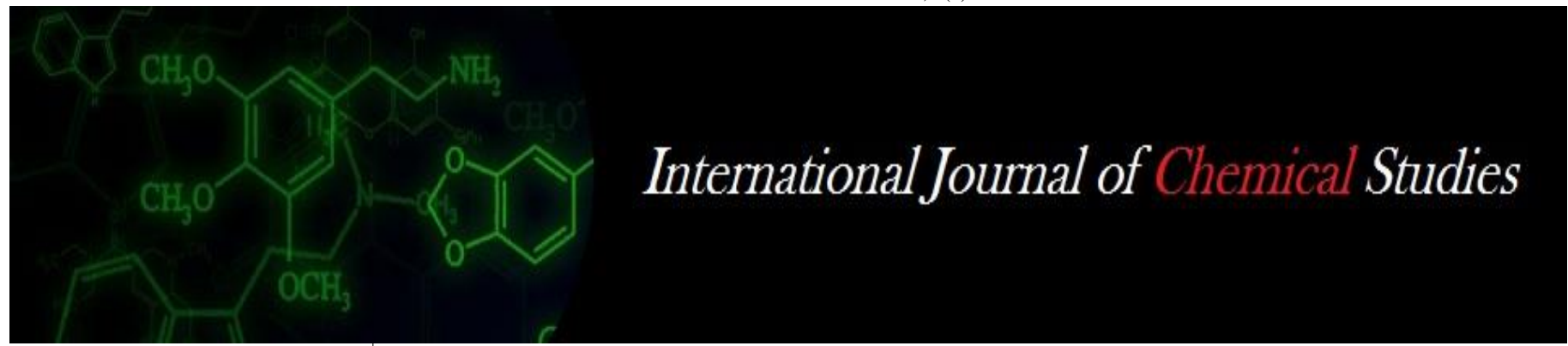

P-ISSN: 2349-8528

E-ISSN: 2321-4902

www.chemijournal.com

IJCS 2020; 8(5): 894-896

(C) 2020 IJCS

Received: 08-06-2020

Accepted: 15-07-2020

Manisha Kachari

College of Horticulture, AAU,

Jorhat, Assam, India

Sangita Mahanta

Department of Horticulture,

AAU, Jorhat, Assam, India

Corresponding Author:

Manisha Kachari

College of Horticulture, AAU,

Jorhat, Assam, India

\section{Popularization of Marigold cv. Seracole for income generation through front line demonstration in Assam}

\author{
Manisha Kachari and Sangita Mahanta
}

DOI: https://doi.org/10.22271/chemi.2020.v8.i5m.10409

\begin{abstract}
The field experiment was carried out during the year 2016 and 2017under KVK's in Sengamari Habigaon village of Dibrugarh district and Moumaikigaon of Golaghat district of Assam for Popularization of marigold cv. Seracole for income generation through front line demonstration. The data were recorded for flower yield, quality and economics of marigold cultivation for summer and winter season. The results showed that in October planting the average weight of flower $6.35 \mathrm{~g}$, flower diameter $7.35 \mathrm{~cm}$, number of ray florets 162.95 , disc florets 75.00 , self life 19.20 days, loose flower life 4.55 days, number of flower per plant 139.0, yield per plant $0.85 \mathrm{~kg}$, yield per plot $14.40 \mathrm{~kg}$, yield per hectare $240.00 \mathrm{q}$ with good compact flower which was closely followed by March planting with $6.10 \mathrm{~g}, 7.10 \mathrm{~cm}$, $156.60,65.80,17.92$ days, 3.40 days, $128.75,0.81 \mathrm{~kg}, 11.30 \mathrm{~kg}$ and $234.00 \mathrm{q}$ respectively. But the benefit cost ratio was showed highest in March planting of 4.85 compared to October planting 3.0 due high demand and price in the summer season.
\end{abstract}

Keywords: Marigold, season, yield, B:C

\section{Introduction}

Marigold (Tagetes erecta L.) belongs to the family Asteraceae, is one of the most profit oriented flower crop grown in India. It can be grown as both perennial and annual plant. The flower blooms in different colour, fragrance and have pleasant appearance with various sizes, shapes and forms. The attractive blooming flower is in high demand in all the holy functions and decoration of wedding venue. The petals have high demand in different areas like medicinal and cosmetic industry. Apart from that Lutein which is the major constituent of xanthophyll is used for colouring food items. It is also grown as trap crop to repel insects and pest to protect the crop from infestation. Marigold is grown commercially for extraction of carotene pigments from petals that are use as feed additives in poultry diet to increase the yellow colour of egg yolk ${ }^{[2]}$ and also help to improve the colour of ornamental fishes as well as fish fillet ${ }^{[3]}$. The performance of marigold cultivars varies in different agro-climatic conditions ${ }^{[10]}$. The Seracole is the day neutral cultivar which performs well and can be grown throughout the year. The farmers of Dibrugrah and Golaghat district were motivated towards flower cultivation seeing its high demand in the market. Generally they grew in October November month but instead of their flower production the farmers could not get enough prices in the market. Therefore, this demonstration programme was conducted in farmer's field with the objective to popularize cultivation of marigold cv. Seracole in summer season so that the farmers get benefited by fetching remunerative profit through offseason market in the districts.

\section{Materials and methods}

The present study on popularisation of marigold cultivar Seracole during summer planting was evaluated through Front Line Demonstration conducted under KVK's in farmer's fields during the first fortnight of March 2016 and 2017. The study was carried out in agro-climatic conditions of Sengamari Habigaon village of Dibrugarh district (Farm-1) and Moumaikigaon of Golaghat district (Farm-2). Healthy cuttings were planted in plot size of $3 \mathrm{~m} \times 2 \mathrm{~m}$ area with $45 \mathrm{~cm}$ x $45 \mathrm{~cm}$ spacing following all the agronomic practices. 
Uniform dose of FYM $5 \mathrm{~kg} / \mathrm{m}^{2}$ and recommended dose of fertilizer N:P:K @ 10:10:10 g/ $\mathrm{m}^{2}$ were applied at the time of planting. The data were recorded for flower yield, quality and economics to see its feasibility in the market.

\section{Results and Discussion}

In the present study the results (Table 1) revealed that the mean value of average weight of flower was $6.35 \mathrm{~g}$ and flower diameter was $7.35 \mathrm{~cm}$ in October planting which was closely followed by March planting with $6.10 \mathrm{~g}, 7.10 \mathrm{~cm}$ respectively. This might be due to the good plants vigour and optimum temperature prevailing during the crop growing period for favourable production of bigger size of flowers with more weight of flower. This results are in conformity with the findings of Chanda and Roychoudhary ${ }^{[4]}$; Lohar et al. ${ }^{[5]}$. The Seracole cultivar during October planting showed number of ray florets and disc florets $(162.95,75.00)$ followed by March planting where number of ray florets and disc florets was $156.60,65.80$ respectively with compact flower in both the seasons. The 'gynomonoecy' sex form in Seracole can be well exploited for the varietal development targeting the loose flower trade market ${ }^{[1]}$. The self life (19.20 days), loose flower life (4.55 days) were obtained in October planting go after by March planting (17.92 days) and (3.40 days) respectively. Increased self life and loose flower life of marigold flower might be due to high retaining of water in the flower cells that prevents drying up of flower. The higher content of chlorophyll, protein and RNA in leaves for longer duration increases self life and restrain the senescence in marigold ${ }^{[8]}$. During winter months due to less apical dominance, there is more initiation of axillary bud resulting to more number of flowers ${ }^{[9]}$. The number of flower per plant was 139.0 and 128.75 in October and March planting respectively. Similar findings were reported by Mohanty et al. ${ }^{[7]}$. The yield per plant $(0.85 \mathrm{~kg})$, yield per plot $(14.40 \mathrm{~kg})$ and yield per hectare $(240.00$ q) were recorded in October planting with close values in March planting $0.81 \mathrm{~kg}, 11.30 \mathrm{~kg}$ and $234.00 \mathrm{q}$ respectively (Table 2). Seracole were found to be best for flower production and showed its stability to most of the characters irrespective of environmental conditions ${ }^{[6]}$. The overall response for planting of marigold cv. Seracole in October was better due to availability of favourable temperature, day length and duration of light before the onset of flower bud initiate and flowering. But the benefit cost ratio (Table 3) was showed highest in March planting of 4.85 compared to October planting 3.0. This is due high demand and price of flower in the lean season that helps the farmers to get high average net return of 582,000 and could able to take it up as business commercially.

Table 1: Flowering Parameters of marigold cv. Seracole

\begin{tabular}{|c|c|c|c|c|c|c|c|c|c|c|c|c|c|c|}
\hline \multirow{2}{*}{ Location } & \multicolumn{2}{|c|}{$\begin{array}{l}\text { Weight of } \\
\text { flower(g) }\end{array}$} & \multicolumn{2}{|c|}{$\begin{array}{c}\text { Flower } \\
\text { diameter }(\mathbf{c m})\end{array}$} & \multicolumn{2}{|c|}{ Flower shape } & \multicolumn{2}{|c|}{ No. of ray florets } & \multicolumn{2}{|c|}{ No. of disc florets } & \multicolumn{2}{|c|}{ Self life(days) } & \multicolumn{2}{|c|}{$\begin{array}{c}\text { Loose flower } \\
\text { life(days) }\end{array}$} \\
\hline & \begin{tabular}{|c|} 
March \\
planting
\end{tabular} & & $\begin{array}{c}\text { March } \\
\text { planting }\end{array}$ & $\begin{array}{l}\text { October } \\
\text { planting }\end{array}$ & & & & & & & & & & \\
\hline & & & & & & & & & & & & & 3.30 & \\
\hline & & & & & & & & & & & & & & \\
\hline Average & 6.10 & 6.35 & 7.10 & 7.35 & Compact & Compact & 156.60 & 162.95 & 65.80 & 75.00 & 17.92 & 19.20 & 3.40 & 4.55 \\
\hline
\end{tabular}

Table 2: Yield parameters of marigold cv. Seracole

\begin{tabular}{|l|c|c|c|c|c|c|c|c|}
\hline \multirow{2}{*}{ Location } & \multicolumn{2}{|c|}{ No. of flowers/plant } & \multicolumn{2}{c|}{ Yield per plant (kg) } & \multicolumn{2}{c|}{ Yield per plot(kg) } & \multicolumn{2}{c|}{ Yield (q/ha) } \\
\cline { 2 - 8 } & $\begin{array}{c}\text { March } \\
\text { planting }\end{array}$ & $\begin{array}{c}\text { October } \\
\text { planting }\end{array}$ & $\begin{array}{c}\text { March } \\
\text { planting }\end{array}$ & $\begin{array}{c}\text { October } \\
\text { planting }\end{array}$ & $\begin{array}{c}\text { March } \\
\text { planting }\end{array}$ & $\begin{array}{c}\text { October } \\
\text { planting }\end{array}$ & $\begin{array}{c}\text { March } \\
\text { planting }\end{array}$ & $\begin{array}{c}\text { October } \\
\text { planting }\end{array}$ \\
\hline Farm 1 & 135.20 & 148.00 & 0.83 & 0.86 & 11.20 & 13.80 & 228.00 & 230.00 \\
\hline Farm 2 & 122.50 & 130.00 & 0.79 & 0.83 & 11.40 & 15.00 & 240.00 & 250.00 \\
\hline Average & 128.75 & 139.00 & 0.81 & 0.85 & 11.30 & 14.40 & 234.00 & 240.00 \\
\hline
\end{tabular}

Table 3: Economics of marigold cultivation cv. Seracole

\begin{tabular}{|c|c|c|c|c|c|c|}
\hline \multirow{2}{*}{ Location } & \multicolumn{2}{|c|}{ Gross return(Rs) } & \multicolumn{2}{c|}{ Net return(Rs) } & \multicolumn{2}{c|}{ B:C } \\
\cline { 2 - 7 } & $\begin{array}{c}\text { March } \\
\text { planting }\end{array}$ & $\begin{array}{c}\text { October } \\
\text { planting }\end{array}$ & $\begin{array}{c}\text { March } \\
\text { planting }\end{array}$ & $\begin{array}{c}\text { October } \\
\text { planting }\end{array}$ & $\begin{array}{c}\text { March } \\
\text { planting }\end{array}$ & $\begin{array}{c}\text { October } \\
\text { planting }\end{array}$ \\
\hline Farm1 & 6,84000 & 460000 & 5,64000 & 3,40000 & 4.70 & 2.83 \\
\hline Farm2 & 7,20000 & 500000 & 6,00000 & 3,80000 & 5.00 & 3.17 \\
\hline Average & 702,000 & 480,000 & 582,000 & 360,000 & 4.85 & 3.00 \\
\hline
\end{tabular}

\section{Conclusion}

From this demonstration study it can be concluded that in both the season cultivation of marigold cultivar Seracole provides healthier yield and quality of flower. But the summer planting marigold would be more lucrative in terms of $\mathrm{B}$ : $\mathrm{C}$ with high net return.

\section{References}

1. Bharathi TU. Intervarietal hybridization of African marigold (Tagetes erecta L.) for improving flower yield and quality, Thesis M.Sc.(hort.), Tamil Nadu agricultural University, 2014. Retrieved from http://hdl.handle.net/10603/263140.
2. Bird JN. Cost effective egg yolk pigmentation in proceedings of the 8th Australian Poultry Science Symposium, 1996, 219.

3. Boonyaralpalin M. Effect of pigments from different sources on colour changes and growth of red (Oreochromis niloticus). Aquaculture. 1989; 79:375-380.

4. Chanda S, Roychoudhury N. The effect of time of planting and spacing on growth, flowering and yield of African marigold (Tagetes erecta L.) cv.'Siracole'. Hort. J. 1991; 4(2):53-56.

5. Lohar A, Majumder J, Sarkar A, Rai B. Evaluation of African marigold (Tagetes erecta L.) Varieties for Morphological and Biochemical Characters under West Bengal Condition Int. J Curr. Microbiol. App. Sci. 2018; 7(10):241-248.

6. Mahanta S, Talukdar MC and Talukdar P. Stability analysis in marigold. Journal of Pharmacognosy and Phytochemistry. 2020; 9(1):1732-1734.

7. Mohanty CR, Mohanty A, Parhi R. Effect of planting dates and pinching on growth and flowering in african marigold cv. sirakole. The Asian Journal of Horticulture. 2015; 10(1):95-99. 
8. Patil KV, Kulkarni BS, Reddy BS, Kerure P, Ingle A. Yield and quality parameters as influenced by seasons and genotypes in marigold (Tagetes erecta L.). Res. J Agric. Sci. 2011; 2(2):344-347.

9. Stirnberg P, Sande KV, Leyser HMO. MAX 1 and MAX 2 control shoot lateral branching in arabidopsis. Development. 2002; 129:1131-41.

10. Tomar GS, Laxman S, Sharma D. Effects of environments on character correlation and heritability in green gram. SABRAO Newsletter. 1972; 4:49-52. 